\title{
Viral Gastroenteritis among Children under 5 Years in Dutsinma Local Government Area, Katsina State, North-West Nigeria, West Africa
}

\author{
Gnimintakpa Joseph, Adejo Godwin \\ Department of Biochemistry and Molecular Biology, Federal University Dutsinma, Katsina State, Nigeria \\ Email: Gniminsco@yahoo.co.uk
}

Received 8 February 2016; accepted 22 February 2016; published 26 February 2016

Copyright (C) 2016 by authors and OALib.

This work is licensed under the Creative Commons Attribution International License (CC BY). http://creativecommons.org/licenses/by/4.0/

(c) (i) Open Access

\begin{abstract}
Rotaviruses and adenoviruses conjointly form the leading cause of epidemic gastroenteritis in developed and developing countries. The prevalence of this array of human viral pathogens in under five years children of Dustin-ma Local Government Area of Katsina State, North-west Nigeria was investigated on diarrheal stool samples of 152 patients of acute viral gastroenteritis by Reverse Transcription Polymerase Chain Reaction (RT-PCR) as approved by the state committee on ethics after parental agreement. Analyses revealed prevalence of $54 \%(35 / 65)$ and $46 \%$ $(30 / 65)$ for rotaviruses and adenoviruses respectively in 2013 and then $62.2 \%(51 / 82)$ for rotaviruses followed by $37.8 \%(31 / 82)$ for adenoviruses in 2014 with a total of 87 rotavirus positive samples $(57.24 \%)$ while 61 samples $(40.13 \%)$ were adenovirus positive. Only 4 samples (3\%) were infected by other diarrheal viral pathogens.
\end{abstract}

\section{Keywords}

Rotavirus, Adenovirus, Viral Gastroenteritis, Children under Five Years, Nigeria

Subject Areas: Virology

\section{Introduction}

Viral gastroenteritis hereafter referred to as VGE is a common disorder among children worldwide. This heath condition is associated with high mortality and morbidity. More than 2 million children are lost to death annually due to diarrheal viral infections, which represents about $19 \%$ of death in this population [1]. In developing countries, the VGE's incidence rate is 2.1 to 3.8 per child from 11 to 48 months of age per year [1] [2]. In Nigeria,

How to cite this paper: Joseph, G. and Godwin, A. (2016) Viral Gastroenteritis among Children under 5 Years in Dutsinma Local Government Area, Katsina State, North-West Nigeria, West Africa. Open Access Library Journal, 3: e2403. 
Diarrhea presents the highest morbidity rate and is the major cause of death during the first year of life [3]. Rotaviruses are double stranded RNA viruses as opposed to human adenoviruses known with double stranded DNA material [4]. While rotavirus has been reported as the leading cause of diarrhea affecting children below 5 years, adenovirus and other viral agents are currently increasingly reported [5]. Even though enteric adenovirus has been identified at $9 \%$ among children with diarrhea, it is established to have very low communicability between close contacts in the same house hold. VGE is usually self-limiting in immunocompetent individuals; however rare fatalities can occur in immunocompromised body systems. Up till 2006, at least 10 cases of laboratory acquired adenovirus infections were reported by Public health Agency of Canada. Meanwhile, it was pointed out that rotavirus was stable at low and high relative humidity and non-stable in the medium range of relative humidity of fecal samples [6]. The potential vehicular role of human hands was also reported. Rotaviral antigens are detectable in hand washings of persons who attend to patients with rotaviral gastroenteritis (GE). These viruses can survive for several days on contaminated non-porous inanimate surfaces [7]. Rotavirus transmission occurs fecal-orally and becomes a critical water quality issue when soil and water become contaminated with feces [8]. The burden of diarrheal disease has now imposed on research institutions the responsibility to disseminate this information and scientifically map out strategies to effectively prevent the spread of this viral disorder in children and abate the rates of mortality and morbidity of VGE in low-income settings of developing countries. It is in this light that we initiated a study to establish the immediate and collateral causes of the spread of VGE among children of less than 5 years [9] in Dutsin-ma local Government Area of Katsina State, NorthWest Nigeria, West Africa.

\section{Materials and Method}

This work was designed to retrospectively investigate 152 diarrheal patients [10] of less than 5 years of age who were diagnosed with enteric adenovirus and rotavirus pathogens in Dustin-ma Local Government's Medical center in Dustin-ma, Katsina State North-West Nigeria, West Africa. These specimen were collected and investigated for the presence of rotavirus and adenovirus antigens within the period from January 2013 to December 2014 in Dustin-ma Hospital and transported to the Department of Biological sciences in Ahmadu Bello University Zaria for analyses using molecular techniques of Polymerase Chain reaction (PCR) for amplification and Reverse Transcription-Polymerase Chain Reaction (RT-PCR) for investigation and electrophoresis.

\subsection{Nucleic Acids Extraction from Stool Samples}

The Nucleic acids from stool samples were isolated following the protocol made public by O'Neil and his colleagues and already used by Catriona Logan and her colleagues in 2006 [4]. RNA and DNA were co-extracted for the isolation of viral nucleic acids from stool samples. All specimens were extracted in a devoted class 2 laminar flow hood using exclusively assigned pipettes and aerosol-resistant pipette tips to ensure the integrity of our results. Fecal samples were prepared as $10 \%$ suspensions with STAR buffer, Roche Diagnostics GmbH, Mannheim, Germany. Equal Chloroform quantities of $0.1 \times$ volume were added, and following mixing, the samples were spun at $8000 \times g$ for $10 \mathrm{~min}$. Stool extract that formed the aqueous layer was removed to a fresh tube and stored at $-80^{\circ} \mathrm{C}$,. The extraction was completed before freezing. Stool extracts of $200 \mu 1$ were further purified with the QIAGEN QIAamp DNA Blood mini kit. Total nucleic acids were adsorbed from the spin columns using $50 \mu \mathrm{l}$ of nuclease-free water. Extracted nucleic acids were stored at $-80^{\circ} \mathrm{C}$. Stool samples were coextracted with a negative extraction control consisting of $200 \mu \mathrm{l}$ of STAR buffer to which no stool had been added.

\subsection{Molecular Techniques for Detection of Rotavirus and Adenovirus}

Reverse Transcription RT-PCR and then electrophoresis were performed. Reverse Transcription was run on the final volume with the help of TaqMan reverse transcription kit (Applied Biosystems) on a GeneAmp 9700 thermocycler from Applied Biosystems following the methodology of Catriona Logan and her colleagues [4]. The reactions contained $1 \times \mathrm{RT}$ buffer, $5.5 \mathrm{mM} \mathrm{MgCl}_{2}, 0.5 \mathrm{mM}$ each deoxynucleoside triphosphate (dNTP), 2.5 $\mu \mathrm{M}$ random hexamer, $0.4 \mathrm{U} / \mu \mathrm{l}$ RNase inhibitor, $1.25 \mathrm{U} / \mu \mathrm{l}$ Multiscribe reverse transcriptase, and $17.5 \mu \mathrm{l}$ of extracted nucleic acids. Extracted nucleic acids were collected from $-80^{\circ} \mathrm{C}$ storage and immediately added to 
200- $\mu$ l thin-walled PCR tubes containing the RT buffer, dNTPs, and $\mathrm{MgCl}_{2}$. The reaction components were denatured by heating at $95^{\circ} \mathrm{C}$ for $5 \mathrm{~min}$ and then quickly chilled on ice for $5 \mathrm{~min}$. Random hexamer, RNase inhibitor, and Multiscribe reverse transcriptase were thereafter added to the mixture. Thermal cycling parameters for the RT reactions were as follows: $10 \mathrm{~min}$ at $25^{\circ} \mathrm{C}, 30 \mathrm{~min}$ at $42^{\circ} \mathrm{C}, 20 \mathrm{~min}$ at $48^{\circ} \mathrm{C}$, and $5 \mathrm{~min}$ at $95^{\circ} \mathrm{C}$. Completed RT reactions were stored at $-20^{\circ} \mathrm{C}$.

\subsection{Primers and Probes for RT-PCR}

All primers and probes were imported from Applied Biosystems. RT reaction samples were analyzed by PCR, in duplicate wells for adenoviral and rotaviral targets on ABI 7000 sequence detector (Applied Biosystems) under universal temperature cycling conditions. RNase and DNase digestion of extracted stool samples were carried out separately to determine the source of nucleic acid responsible for PCR amplification, using RNase Cocktail and TURBO DNA-free (Ambion (Europe) Ltd at $37^{\circ} \mathrm{C}$ for $30 \mathrm{~min}$ [4].

\subsection{RT-PCR Amplification Reaction}

Amplification carried on a GeneAmp PCR system 9700 (Applied Biosystems) under the initial DNA denaturation temperature $95^{\circ} \mathrm{C}$ for $10 \mathrm{~min}$; 45 amplification cycles with denaturation at $94^{\circ} \mathrm{C}$ for $45 \mathrm{~s}$, annealing at 50 to $55^{\circ} \mathrm{C}$ for $45 \mathrm{~s}$, and extension at $70^{\circ} \mathrm{C}$ for $92 \mathrm{~s}$; and a final incubation at $72^{\circ} \mathrm{C}$ for $10-12 \mathrm{~min}$ [4].

\subsection{Electrophoresis}

Amplified PCR products were analyzed by electrophoresis on $2 \%$ ethidium bromide-stained agarose gels and viewed under Ultra-Violet illumination.

\section{Results}

In total, 87 samples (57.2\%) were positive of rotavirus and 61 (40.1\%) were adenovirus positive, only 4 samples (3\%) were infected by other viral pathogens. Clinical laboratory data complementary information on one hand and demographic data on the other provided supplementary information regarding the measure of interest in hygiene standards and accessibility to potable source of water in affected communities. It was then derived that 84 patients (55.2\%) use domestic water supplied conjointly by the dams of Dutsinma and Zobe located in the same Local Government area which is supplied to populations without treatment and 68 (44.8\%) patients lived in remote villages with no drainage nor sewage network. The results of the investigation of rotavirus and adenovirus in stool samples of under five years VGE patients in Dutsinma Local Government Area of Katsina State in Nigeria are tabulated (Table 1).

\section{Discussion}

Our investigation depicted the rotavirus detection rate of $57.2 \%$ (87/152) of the samples while 61 samples $40.1 \%$ (61/152) were adenovirus positive. Viral gastroenteritis is an inflammation of the stomach and intestines [11] caused by one of any of the numerous viral pathogens which spreads through close contact [12] with carriers of the virus, or contaminated food or water [13]. In detailed studies, monthly surveillance has revealed highest frequency pick over a 2 year period between July and April with the 2 major pathogens of interest (rotavirus and adenovirus). Of 152 patients, 5.9\% (9/152) were positive for rotavirus and 2\% (3/152) with adenovirus for the month of April 2013. In April 2014 the frequency ascended to 7.2\% (11/152) for rotavirus and 3.3\% (5/152) with adenovirus. This may be assumably caused by drought severity in April that Dutsinma and Zobe dams serve both as drinking points for cattle and also supply sources for the communities, increasing viral proliferation among the populations benefiting from water poor supply structures available in Dutsinma Local Government [5]. In July 2013 the frequencies of rotavirus and adenovirus revealed 5.9\% (9/152) and 2.6\% (4/152) respectively, these data rose to $7.2 \%$ (11/152) for rotavirus and $4.6 \%$ (7/152) with adenovirus in July 2014. These statistics might be justified by rain waters which fulfill vehicular functions for pathogens [5] [14] since most of these villages have no drainage nor sewage systems, the highest rain fall is observed in the savannah region of Nigeria in the months of July, August and September. 
Table 1. Viral infections per month per village in Dutsinma Local Government Area, Katsina State, Nigeria.

\begin{tabular}{|c|c|c|c|c|c|c|c|c|c|c|c|c|c|c|c|}
\hline \multirow{2}{*}{ Mths } & & \multicolumn{2}{|c|}{ Karofi } & \multicolumn{2}{|c|}{ Makera } & \multicolumn{2}{|c|}{ Kuki } & \multicolumn{2}{|c|}{ Shema } & \multicolumn{2}{|c|}{ Tabawa } & \multicolumn{2}{|c|}{ Wanruma } & \multicolumn{2}{|c|}{ Dutsinma } \\
\hline & & $2 \times 13$ & $2 \times 14$ & $2 \times 13$ & $2 \times 14$ & $2 \times 13$ & $2 \times 14$ & $2 \times 13$ & $2 \times 14$ & $2 \times 13$ & $2 \times 14$ & $2 \times 13$ & $2 \times 14$ & $2 \times 13$ & $2 \times 14$ \\
\hline \multirow{2}{*}{ Jan } & Rota & 1 & & & & & & 1 & & 1 & & & & & 1 \\
\hline & Adeno & & & & & & & 1 & & & & & & & 1 \\
\hline \multirow{2}{*}{ Feb } & Rota & 1 & & & & & 1 & 1 & & & 1 & & & & 1 \\
\hline & Adeno & & & 1 & & & 1 & & & & & & & & \\
\hline \multirow{2}{*}{ Mar } & Rota & 1 & & & 1 & & & & 1 & & & & & & 1 \\
\hline & Adeno & & & 1 & & & 1 & & 1 & & & 1 & & & 2 \\
\hline \multirow{2}{*}{ Apr } & Rota & 2 & 2 & & 2 & 2 & & & 2 & & 2 & 2 & & 3 & 3 \\
\hline & Adeno & 1 & & 1 & & 1 & 1 & & 2 & & & 1 & & 1 & \\
\hline \multirow{2}{*}{ May } & Rota & & 1 & & & 1 & & & 1 & & & & 1 & & 1 \\
\hline & Adeno & 1 & & & 1 & 1 & & 1 & & & & & 1 & & 1 \\
\hline \multirow{2}{*}{ Jun } & Rota & 1 & & 1 & & & 1 & & & & & & 1 & & 1 \\
\hline & Adeno & 1 & & 1 & & & 1 & & & 1 & & 1 & & 1 & \\
\hline \multirow{2}{*}{ Jul } & Rota & 1 & 2 & 2 & 1 & 3 & 2 & 1 & & 2 & 3 & & 1 & & 2 \\
\hline & Adeno & 2 & & 1 & & 1 & 1 & 1 & 1 & 1 & 1 & & 1 & 1 & \\
\hline \multirow{2}{*}{ Aug } & Rota & 1 & & & & & & & 1 & & 1 & & & & 1 \\
\hline & Adeno & 1 & & 1 & & & & 1 & & & & & & & \\
\hline \multirow{2}{*}{ Sep } & Rota & & & 1 & & 1 & & 1 & 1 & & & 1 & & & 1 \\
\hline & Adeno & 1 & & & 1 & & & & 1 & & & & & & \\
\hline \multirow{2}{*}{ Oct } & Rota & & 1 & & & & 1 & 1 & & & 1 & & 1 & & 1 \\
\hline & Adeno & 1 & 1 & & 1 & & & & 1 & & 1 & & & & 2 \\
\hline \multirow{2}{*}{ Nov } & Rota & 1 & & & 1 & & & 1 & & & & & 1 & & 1 \\
\hline & Adeno & 1 & & & 1 & & & & 1 & & 1 & & & & 1 \\
\hline \multirow{2}{*}{ Dec } & Rota & & 1 & & & & & & & & & & & & \\
\hline & Adeno & & & & 1 & & 1 & & & & & & & & \\
\hline
\end{tabular}

Rota: rotavirus; Adeno: adenovirus; com: communities; Yrs: years; Mths: months.

\section{Conclusion}

These findings highlight the need for a better picture of the burden of children under 5 years VGE's diarrhea mortality and morbidity that will ultimately result in practical planning [13] for the prioritization of intervention policies for potable water supply to populations in low income settings in developing countries [15]. This can be achieved by setting up systems able to generate representative quality data on a regular basis using local co-variants from remote population of considered locations to restrict the spread of these pathogens.

\section{References}

[1] de Oliveira Ferreiraa, C.E., Rabonia, S.M., Pereiraa, L.A., Nogueiraa, M.B., Vidala, L.R.R. and Almeidaa, S.M. (2012) Viral Acute Gastroenteritis: Clinical and Epidemiological Features of Co-Infected Patients. The Brazilian Journal of Infectious Diseases, 16, 267-272.

[2] Pison, G., Trape, J.F., Lefebvre, M. and Enel, C. (1993) Rapid Decline in Child Mortality in a Rural Area of Senegal. 
International Journal of Epidemiology, 22, 72-80. http://dx.doi.org/10.1093/ije/22.1.72

[3] Anker, M. (1993) The Effect of Misclassification Error on Reported Cause-Specific Mortality Fractions from Verbal Autopsy. International Journal of Epidemiology, 26, 1090-1096. http://dx.doi.org/10.1093/ije/26.5.1090

[4] Logan, C., O’Leary, J.J. and O’Sullivan, N. (2006) Real-Time Reverse Transcription-PCR for Detection of Rotavirus and Adenovirus as Causative Agents of Acute Viral Gastroenteritis in Children. Journal of Clinical Microbiology, 44, 3189-3195. http://dx.doi.org/10.1128/JCM.00915-06

[5] Vincent, M. and Tablang, F. (2014) Viral Gastroenteritis. Medscape, December 2014.

[6] Moe, K. and Shirley, J.A. (1982) The Effects of Relative Humidity and Temperature on the Survival of Human Rotavirus in Faeces. Archives of Virology, 72, 179-86. http://dx.doi.org/10.1007/BF01348963

[7] Ansari, S.A., Sattar, S.A., Springthorpe, V.S., Wells, G.A. and Tostowaryk, W. (1988) Rotavirus Survival on Human Hands and Transfer of Infectious Virous to Animate and Non-Porous Inanimate Surfaces. Journal of Clinical Microbiology, 26, 1513-1518.

[8] Davidson, P.C., Kuhlenschmidt, T.B., Bhattarai, R., Kalita, P.K. and Kuhlenschmidt, M.S. (2013) Investigation of Rotavirus Survival in Different Soil Fractions and Temperature Conditions. Journal of Environmental Protection, 4, 1-9. http://dx.doi.org/10.4236/jep.2013.47A001

[9] Ham, H., Oh, S., Jang, J., Jo, S., Choi, S. and Pak, S. (2014) Prevalence of Human Astrovirus in Patients with Acute Gastroenteritis. Annals of Laboratory Medicine, 34, 145-147. http://dx.doi.org/10.3343/alm.2014.34.2.145

[10] Marcus, V., Mohammed, M.S., Mustapha, M., Igwilo, I. and Gnimintakpa, J. (2014) Extractibility of Thevetia Peruviana Glycoside Using Various Organic Solvents. Journal of Biology, Agriculture and Healthcare, 4, nb 14.

[11] Khamrin, P., Maneekam, N., Thongprachum, A., Chaimongkol, N., Okitsu, S. and Ushijima, H. (2010) Emergence of New Norovirus Variants and Genetic Heterogeneity of Noroviruses and Sapoviruses in Children Admitted to Hospital with Diarrhea in Thailand. Journal of Medical Virology, 82, 289-296. http://dx.doi.org/10.1002/jmv.21640

[12] Bailey, P., Tsui, A.O., Janowitz, B., Dominik, R. and Araujo, L. (1990) A Study of Infant Mortality and Causes of Death in a Rural North-East Brazilian Community. Journal of Biosocial Science, 22, 349-363. http://dx.doi.org/10.1017/S002193200001871X

[13] Boschi-Pinto, C., Velebit, L. and Shibuya, L. Estimating Child Mortality Due to Diarrhoea in Developing Countries. Bulletin of the World Health Organization.

[14] Lee, J.I., Park, S.H., et al. (2009) Surveillance of Acute Gastroenteritis in Seoul Korea during May 2004 and June 2007. Journal of Bacteriology Viralogy, 39, 363-371. http://dx.doi.org/10.4167/jbv.2009.39.4.363

[15] Baqui, A.H., Sabir, A.A., Begum, N., Arifeen, S.E., Mitra, S.N. and Black, R.E. (2001) Causes of Childhood Deaths in Bangladesh: An Update. Acta Paediatrica, 90, 682-690. http://dx.doi.org/10.1111/j.1651-2227.2001.tb02434.x 